Institute of $\mathbf{F}_{\text {ood and }} \mathbf{A}_{\text {gricultural }} \mathbf{S}_{\text {ciences }}$

\title{
Redbanded Thrips, Selenothrips rubrocinctus (Giard) (Insects: Thysanoptera: Thripidae) ${ }^{1}$
}

H. A. Denmark and D. O. Wolfenbarger ${ }^{2}$

\section{Introduction}

Selenothrips rubrocinctus, the redbanded thrips, was described by Giard (1901) as Physopus

rubrocinctus. He received specimens from Guadeloupe, West Indies, where it was causing considerable damage to cacao. It was referred to earlier as the cacao thrips. The earliest report relating to this thrips was a report by W.E. Broadway in 1898, when he called attention to the "blight" of cacao.

\section{Distribution}

There is some question about the origin of this thrips. Although it was described from specimens originating in the West Indies, it may have been first observed in Sri Lanka. Sri Lanka is not given as part of the distribution because the thrips has never been reported from there since the first record by E.E. Green (Trop. Agric. 27: 248, 1906). It is a tropicalsubtropical species and is found in the following areas: Asia -- China, Taiwan, Malaya and the Philippine Islands; Africa -- Fernando, Ghana, Ivory Coast, Nigeria, Principe, Democratic Republic of the Congo, San Thome, Sierra Leone, Tanzania, Uganda,
Australasia and Pacific Islands -- Hawaiian Islands, Mariana Islands, New Caledonia, Papua, New Guinea, and Solomon Islands; North America -Florida, Mexico; Central America -- Costa Rica, Honduras, Panama; West Indies; South America -Brazil, Guiana, Ecuador, Peru, Suriname, and Venezuela. In Florida, it is found from Key West to Macclenny, but more generally it is found from the Orlando area south.

\section{Description and Life Cycle}

The female is about $1.20 \mathrm{~mm}$ in length and has a dark brown to black body underlain by red pigment chiefly in the first 3 abdominal segments; the anal segments retain a reddish black color, and the wings are dark. The male is similar, but smaller and is seldom collected. The larva is light yellow to orange with abdominal segments 1 and 2 and anal segments bright red. The nymph and pupa are light yellow to orange with the first three and last segments of the abdomen bright red. The life cycle is completed in Florida in about three weeks, and there are several generations a year.

1. This document is EENY-099 (originally published as DPI Entomology Circular No. 108), one of a series of Featured Creatures from the Entomology and Nematology Department, Florida Cooperative Extension Service, Institute of Food and Agricultural Sciences, University of Florida. Published: June 1999. This document is also available on Featured Creatures Website at http://creatures.ifas.ufl.edu. Please visit the EDIS Website at http://edis.ifas.ufl.edu. Additional information on these organisms, including many color photographs, is available at the Entomology and Nematology Department WWW site at http://entnemdept.ifas.ufl.edu/.

2. H. A. Denmark and D. O. Wolfenbarger, Florida Department of Agriculture and Consumer Services, Division of Plant Industry, Gainesville, FL.

The Institute of Food and Agricultural Sciences is an equal opportunity/affirmative action employer authorized to provide research, educational information and other services only to individuals and institutions that function without regard to race, color, sex, age, handicap, or national origin. For information on obtaining other extension publications, contact your county Cooperative Extension Service office. Florida Cooperative Extension Service/Institute of Food and Agricultural Sciences/University of Florida/Christine Taylor Waddill, Dean. 


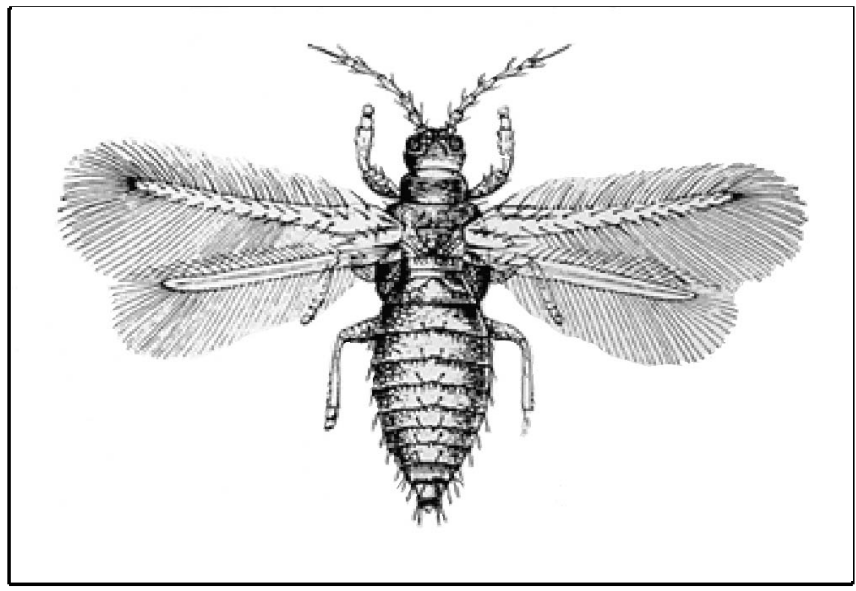

Figure 1. Redbanded thrips adult. Credits: Division of Plant Industry

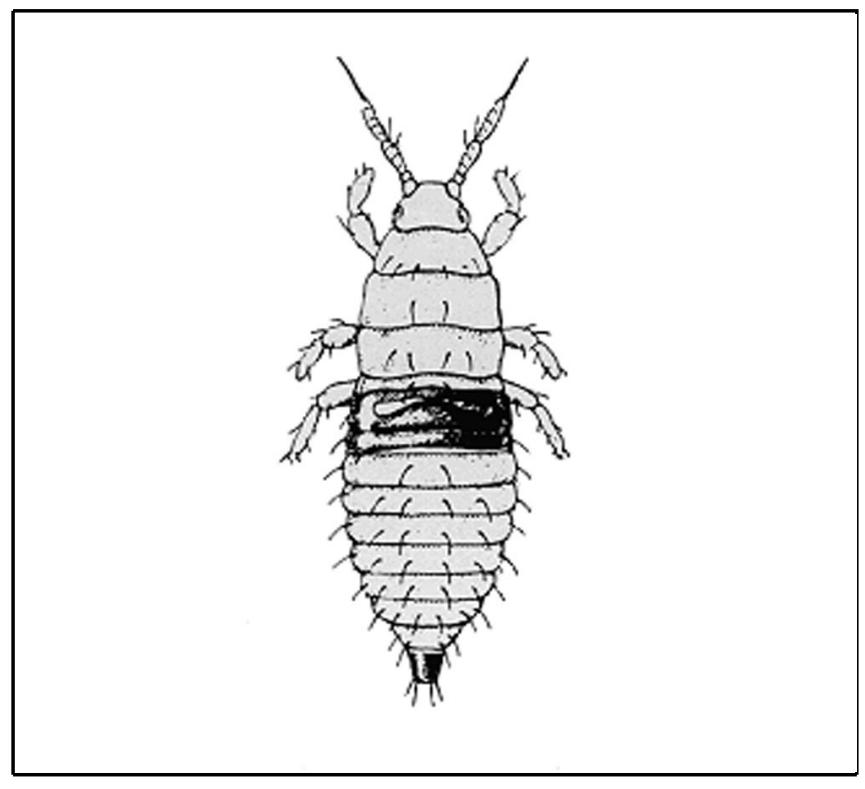

Figure 2. Redbanded thrips larva. Credits: Division of Plant Industry

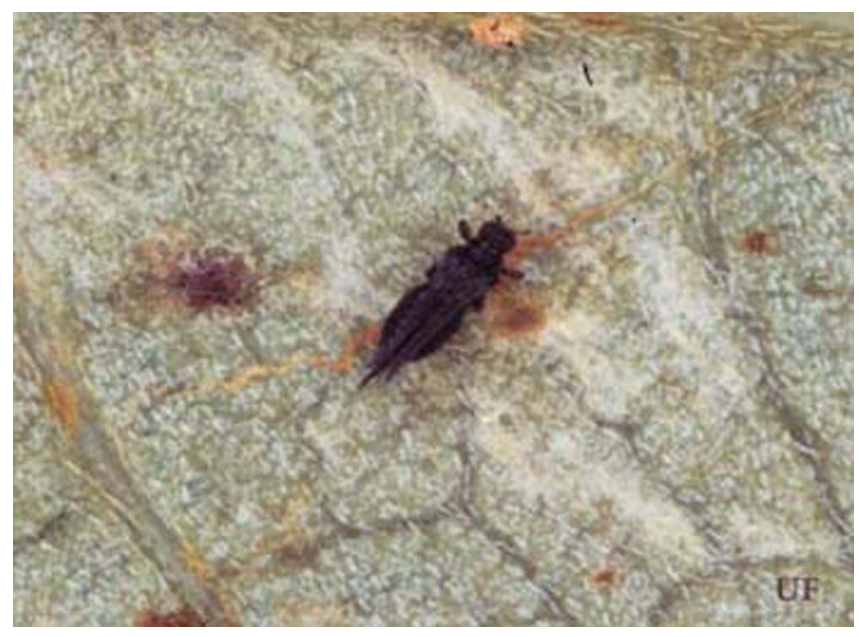

Figure 3. Adult of the redbanded thrips, Selenothrips rubrocinctus (Giard). Credits: Division of Plant Industry

\section{Hosts}

The redbanded thrips is a pest of many plants. The locality and its flora usually determine the more prevalent hosts. In the West Indies, it has been a serious pest of cacao and mango. The species of tropical fruit trees, ornamentals and shade trees that it attacks are too numerous to list here. The favorite tropical fruit hosts in Florida are mango and avocado. Recently, it was also a problem in sweetgum trees in central Florida.

\section{Economic Importance}

The larvae and adults feed on the foliage and the fruit by piercing the epidermis with their mouthparts. Redbanded thrips prefer young foliage and their feeding and causes leaf distortion and leaf drop. The thrips destroys the cells on which it feeds, causes some leaf distortion, injury to the fruit, and leaves unsightly dark colored droplets or blotches of excrement on the leaf surface. A more serious injury is leaf drop, which may denude trees. Honeydew excretory products from red-banded thrips and other insect infestations fall to leaves, fruits or objects beneath, giving rise to the objectionable fruit-degrading, black sooty mold.

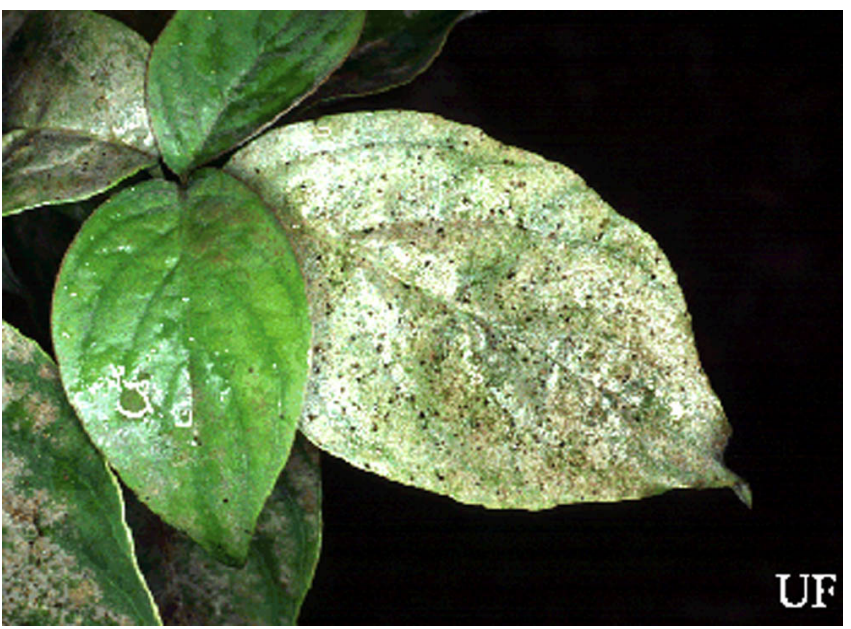

Figure 4. Typical thrips damage, notice the cell damage and droplets of excrement. Credits: University of Florida

\section{Management}

Chemical controls are not always necessary for this thrips, as natural controls are apparently effective most of the time. However, if chemical control is required, consult the following: 
Insect Management Guide for Ornamentals

Insect Management Guide for Fruit

\section{Selected References}

Fennah, R.G. 1965. The influence of environmental stress on the cacao tree in predetermining the feeding sites of cacao thrips, Selenothrips rubrocinctus (Giard), on leaves and pods. Bull. Ent. Res. 56: 333.

Giard, A. 1901. Sur un thrips (Physopus rubrocinctus nov. sp.) nuisible au cacaoyer. Soc. Ent. France, Bull. 15: 263-265.

Hecht, O. 1952. "Nota acerca de Selenothrips rubrocinctus Giard, playa del cacaotero," Fitofilo San Jacinto, D.F., Mexico. An. 6, N. 5: 33-42.

Koehler, P.G., D.E.Short and T.R. Fasulo. (1998). Pests In and Around the Home. UF/IFAS, CD-ROM.

Mizell, R.F., D.E. Short and T.R. Fasulo. (May 1998). WoodyPest. UF/IFAS.

http://woodypest.ifas.ufl.edu/ (July 1999).

Reyne, A. 1921. De cacaothrips (Heliothrips rubrocinctus Giard). Suriname Dept. v.d. Landbouw Bull. 44. 214 p.

Russell, H.M. 1912. The red-banded thrips. Papers on insects injurious to citrus and other subtropical fruits. USDA Bur. Ent. Bull. 99: 17-29. 